Journal IMAGE | Volume 9, Number 2, November 2020, page 79-91

\title{
PENGARUH KEAMANAN, KEANDALAN DAN KEPUASAN TERHADAP LOYALITAS KONSUMEN DALAM MENGGUNAKAN MOBILE BANKING
}

\author{
Arry Dwi Handoko ${ }^{1}$, Ronny ${ }^{2}$ \\ ${ }^{1,2}$ Magister Manajemen (Program Pascasarja, STIE Perbanas, Surabaya, Indonesia) \\ ardefila@gmail.com ${ }^{1}$, ronny @ perbanas.ac.id ${ }^{2}$
}

\begin{abstract}
This study aims to prove the effect of security, reliability and satisfaction of using mobile banking on customer loyalty Bank Rakyat Indonesia. The research was conducted using quantitative methods, and data were collected by distributing questionnaires to 100 BRI customers in the city of Surabaya. With Structural Equation Modeling (SEM) data analysis techniques and the help of the WarpPLS tool, this study proves that security and satisfaction can increase customer loyalty. Meanwhile, reliability has no effect on customer loyalty. Reliability does not affect loyalty because the majority of respondents' work place payroll is through BRI. Thus, respondents use BRI mobile banking for reasons of practicality because they already have a BRI account. And until now, respondents are satisfied with BRI's mobile banking service. From the results of this study, the authors recommend that BRI increase mobile banking users by establishing a cooperation in paying employee salaries through BRI's payroll. This method is more effective in increasing BRI mobile banking users than through individual promotions.
\end{abstract}

Keywords: security; reliability; satisfaction; loyalty; mobile banking

\begin{abstract}
Abstrak
Penelitian ini bertujuan mengetahui pengaruh keamanan, keandalan serta kepuasan penggunaan mobile banking terhadap loyalitas nasabah pada Bank Rakyat Indonesia (BRI). Penelitian dilakukan dengan metode kuantitatif, dan data dikumpulkan dengan menyebarkan kuisioner pada 100 nasabah BRI di kota Surabaya. Dengan tehnik analisis data Struktural Equation Modeling (SEM) dan bantuan alat WarpPLS, penelitian ini menyatakan bahwa keamanan dan kepuasan dapat meningkatkan loyalitas nasabah, sementara keandalan tidak berpengaruh terhadap loyalitas nasabah. Keandalan tidak berpengaruh terhadap loyalitas karena payroll perusahaan tempat kerja mayoritas responden melalui BRI. Sehingga, responden menggunakan mobile banking BRI dengan alasan kepraktisan karena telah memiliki rekening BRI. Dan sampai dengan saat ini responden merasa puas dengan layanan mobile banking BRI. Berdasarkan hasil penelitian ini, penulis merekomendasikan kepada BRI untuk meningkatkan pengguna mobile banking dapat diupayakan dengan menjalin kerjasama pembayaran gaji karyawan perusahaan melalui payroll BRI. Cara ini lebih efektif untuk meningkatkan pengguna mobile banking BRI daripada melalui promosi individu.
\end{abstract}

Kata kunci: keamanan; keandalan; kepuasan; loyalitas; mobile banking

Corresponding author : ardefila@gmail.com

History of article: Received: September 2020, Revised: November 2020, Published: Januari 2021 


\section{PENDAHULUAN}

Tuntutan pengembangan layanan perbankan digital (digital banking) berjalan seiring dengan perkembangan teknologi informasi. Layanan ini bertujuan untuk meningkatkan efisiensi kegiatan operasional dan mutu pelayanan bank kepada nasabah. Dengan layanan digital banking, pelayanan terhadap nasabah dapat dilakukan lebih cepat dan real time. Oleh karena itu, bank perlu mengembangkan strategi bisnis yang mengarah pada layanan digital banking.

Layanan digital banking merupakan layanan atau kegiatan perbankan dengan menggunakan sarana elektronik atau digital milik Bank, dan/atau media digital milik calon nasabah dan/atau nasabah Bank, yang dilakukan secara mandiri. Dengan layanan digital banking ini memungkinkan calon nasabah dan/atau nasabah Bank untuk memperoleh informasi, berkomunikasi, melakukan registrasi, pembukaan dan penutupan rekening, melakukan transaksi perbankan, termasuk memperoleh informasi lain dan transaksi di luar produk perbankan, seperti nasihat keuangan (financial advisory), investasi, transaksi sistem perdagangan berbasis elektronik (e-commerce), serta kebutuhan nasabah yang lain.

Pengembangan strategi bisnis layanan digital banking memerlukan infrastruktur yang memadai, diantaranya penyesuaian teknologi informasi, manajemen risiko, business model, business process, internal control, dan sumber daya manusia. Infrastruktur tersebut dibutuhkan untuk mendukung keamanan, kenyamanan, serta keandalan layanan digital banking dalam menyediakan informasi, komunikasi, registrasi, pembukaan dan penutupan rekening, serta pemrosesan transaksi (Otoritas Jasa Keuangan, 2015).

Penerapan layanan digital banking di Indonesia diawali dengan penyelenggaraan "digital branch", yaitu sarana bank yang berfungsi secara khusus untuk memproses registrasi nasabah dan pembukaan rekening secara mandiri. Sarana perbankan untuk meningkatkan pelayanan kepada nasabah secara aman, nyaman, dan efektif, diantaranya melalui media elektronik atau dikenal dengan Electronic Banking (e-banking). E Banking merupakan layanan yang memungkinkan nasabah Bank untuk memperoleh informasi, melakukan komunikasi, dan melakukan transaksi perbankan melalui media elektronik seperti Automatic Teller Machine (ATM), Electronic Data Capture (EDC)/ Point Of Sales (POS), internet banking, SMS banking, mobile Banking, e-commerce, phone Banking, dan video banking.

E-Banking memberikan banyak manfaat baik bagi nasabah, bank, dan pihak otoritas. Bagi nasabah, e-banking memberikan kemudahan bertransaksi dalam hal waktu, tempat, dan low cost transaction. Nasabah tidak perlu mendatangi kantor bank untuk memperoleh informasi atau melakukan transaksi perbankan. Bahkan untuk beberapa produk e-banking nasabah dapat bertransaksi selama 24 jam dengan menggunakan laptop atau perangkat mobile seperti telepon seluler yang dapat dibawa kemana saja selama terhubung dengan jaringan internet dan/atau SMS.

Bagi bank, e-banking merupakan pusat pendapatan berbasis komisi (fee based income) serta mampu menghemat biaya operasional apabila dibandingkan dengan pelayanan transaksi melalui kantor cabang. Biaya operasional kantor cabang membutuhkan biaya yang relatif besar untuk membayar karyawan, sewa gedung, pengamanan, listrik, dan lainnya. Sementara bagi pemerintah, perkembangan teknologi e-banking mendorong mewujudkan masyarakat less cash society. Less cash society adalah gaya hidup dengan menggunakan media transaksi atau uang elektronik dalam bertransaksi. Less cash society selain dapat meningkatkan sistem pembayaran yang cepat, 
aman, dan efisien, untuk mempercepat perputaran aktivitas ekonomi dan stabilitas sistem keuangan, juga dapat mencegah tindak pidana kriminal (karena tidak membawa uang tunai) maupun tindak pidana pencucian uang.

Ketika menggunakan layanan e-banking, terdapat beberapa faktor yang akan dipertimbangkan oleh nasabah sebelum memutuskan untuk menggunakan layanan $e$ banking suatu bank, mengingat hampir semua perbankan saat ini telah memiliki dan mengembangkan $e$ - banking. Faktor -faktor tersebut adalah keamanan, keandalan, kualitas informasi, kemudahan dalam mengakses, kualitas layanan dan faktor lainnya.

Dalam era persaingan perbankan yang sangat ketat saat ini, maka penelitian terhadap faktor-faktor yang mempengaruhi keputusan nasabah untuk menggunakan layanan $e$ banking perlu dikaji untuk mengetahui loyalitas nasabah. Selain itu dengan memahami berbagai faktor-faktor tersebut maka dapat digunakan bank untuk melakukan inovasi dan pengembangan produk layanan $e$ - banking agar dapat memberikan kepuasan nasabah.

Bank Rakyat Indonesia (BRI) adalah salah satu bank milik Pemerintah terbesar di Indonesia. BRI memiliki Kantor Cabang dan Unit terbanyak yang menjangkau hampir di seluruh wilayah tanah air. PT Bank Rakyat Indonesia (Persero) Tbk sebagai salah satu Bank di Indonesia yang sangat fokus dalam pengembangan layanan e-banking, hal ini tercermin dalam perkembangan jumlah user $e$ banking yang selama 3 tahun terakhir (20162018) yang terus mengalami kenaikan.

Dari Gambar 1 dapat dilihat perkembangan jumlah pengguna layanan $e$ banking di Bank BRI selama 3 tahun terakhir. Pada tahun 2018 jumlah rekening nasabah sebanyak 83.480.200. Dari jumlah pemilik rekening tersebut, pengguna Mobile Banking di BRI sebanyak 13.115.906; sementara jumlah pengguna ATM mengalami penurunan dibanding tahun 2017 sebanyak 44.761.600.

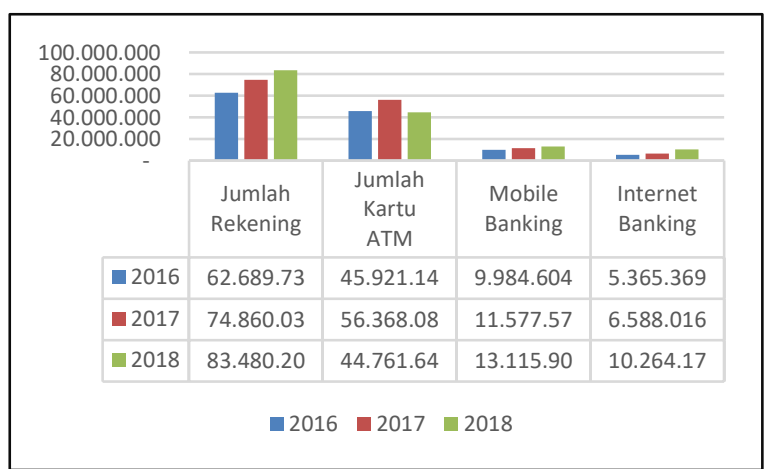

Gambar 1. User E-Banking BRI Th 2016-2018

Sumber: BRISIM (BRI Information System)

Dari Gambar 1 dapat dilihat perkembangan jumlah pengguna layanan $e$ banking di Bank BRI selama 3 tahun terakhir. Pada tahun 2018 jumlah rekening nasabah sebanyak 83.480.200. Dari jumlah pemilik rekening tersebut, pengguna Mobile Banking di BRI sebanyak 13.115.906; sementara jumlah pengguna ATM mengalami penurunan dibanding tahun 2017 sebanyak 44.761.600.

Peningkatan jumlah pengguna mobile banking terus diikuti sampai dengan tahun 2020. Hal ini karena perusahaan berkonsentasi melakukan promosi yang gencar diiringi dengan strategi pemasaran melalui bundling produk antara produk tabungan dengan Mobile Banking.

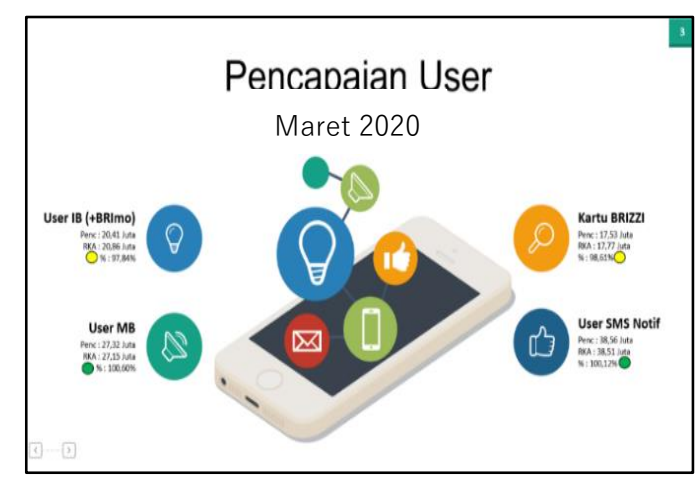

Gambar 2. User E-Banking BRI Th. 2020 Sumber: Divisi Retail dan Payment BRI

Kegiatan promosi telah dilakukan secara massif oleh seluruh pekerja melalui programprogram pemasaran produk mobile banking, sehingga diperoleh hasil pengguna user mobile banking BRI sebanyak 27,32 juta pengguna 
yang tersebar di seluruh wilayah Indonesia, seperti yang ditunjukkan dalam gambar 2:

Data ini menunjukkan bahwa telah banyak nasabah BRI yang beralih ke layanan mobile banking daripada menggunakan ATM. Hal ini perlu diteliti apakah peningkatan jumlah pengguna mobile banking ini dipengaruhi oleh faktor keamanan, kenyamanan serta keandalan layanan mobile banking BRI. Penelitian serupa telah dilakukan oleh Shahriari (2014) yang menemukan bahwa terdapat hubungan yang signifikan antara kualitas layanan, kepercayaan, reputasi dan kebiasaan terhadap loyalitas pelanggan.

Penelitian lain yang dilakukan oleh Wicaksono, dkk (2015) yang dilakukan dengan survei pada nasabah PT. BRI (Persero) Tbk Kantor Cabang Malang Kawi, Kanwil Malang diperoleh hasil bahwa kepuasan berpengaruh signifikan terhadap loyalitas nasabah. Penelitian lain oleh Rosyid, dkk (2019) menyatakan bahwa E-servqual dan kepuasan pengguna mobile banking berpengaruh terhadap loyalitas nasabah. Berdasarkan latar belakang dan penelitian terdahulu tersebut, maka penelitian ini ingin mengetahui:

1. Apakah faktor keamanan dapat meningkatkan loyalitas nasabah BRI dalam menggunakan Mobile Banking?

2. Apakah faktor keandalan dapat meningkatkan loyalitas nasabah BRI dalam menggunakan Mobile Banking?

3. Apakah faktor kepuasan dapat meningkatkan loyalitas nasabah BRI dalam menggunakan Mobile Banking?

\section{KAJIAN PUSTAKA}

Perkembangan loyalitas pelanggan dalam perbankan online telah menjadi masalah mendasar karena pengaruh positif dan konstruktif terhadap produktivitas jangka panjang bank. Dengan meningkatnya akses Internet, kompetisi hanya berjarak satu titik. Loyalitas pelanggan di sektor perbankan online tampaknya penting untuk bank elektronik baik dalam arti kompetitif maupun ekonomi. Oleh karena itu, ada kebutuhan untuk memahami bagaimana loyalitas pelanggan di sektor perbankan online dibuat.

\section{Perbankan Online}

Perkembangan internet dan Web telah menjadi perkembangan yang paling menarik di bidang data dan teknologi pertukaran dalam beberapa tahun terakhir. Dengan meningkatnya akses Internet, fenomena memanfaatkan layanan Perbankan Online (atau Internet banking atau E-banking) meledak. Perbankan online mengacu pada layanan perbankan yang disediakan melalui situs web aman yang dioperasikan oleh penyedia bank, di sepanjang jalur ini mendorong penggunaan Internet sebagai saluran pengiriman jarak jauh. Perbankan online memungkinkan pelanggan bank dengan akses yang sesuai untuk mengelola keuangan mereka dengan ketidaknyamanan yang dapat diabaikan karena menyediakan pendekatan cepat dan nyaman untuk melakukan pertukaran perbankan yang berbeda menggunakan situs web perbankan online dari rumah, kantor atau di tempat lain.

\section{Hubungan Keamanan dengan Loyalitas Nasabah}

Loyalitas pelanggan sangat penting dalam perdagangan elektronik. Loyalitas pelanggan didefinisikan sebagai komitmen yang dipegang teguh untuk membeli kembali atau melindungi kembali produk / layanan secara konsisten di masa depan (Balbhadra \& Rathod, 2016). Loyalitas pelanggan mengarah pada peningkatan manfaat melalui peningkatan pendapatan, menurunkan biaya menarik pelanggan baru, mengurangi sensitivitas pelanggan terhadap harga, dan mengurangi biaya menyesuaikan pelanggan dengan metode operasional asosiasi (Nayebzadeh,2013).

Membangun loyalitas pelanggan adalah salah satu tantangan terbesar dalam $e$ commerce B2C hari ini. Penelitian Hjälte \& Larsson (2004), menunjukkan bahwa loyalitas menciptakan komitmen pada pelanggan untuk mengeksekusi dengan asosiasi tertentu dan sering membeli barang dan layanannya. 
Faktor-faktor yang mempengaruhi loyalitas sangat penting untuk diteliti karena merupakan kunci sukses keberhasilan proses bisnis. Loyalitas pelanggan terikat dengan menarik pelanggan yang benar, membuat mereka membeli, sering membeli, membeli dalam jumlah yang lebih tinggi Onditi et al. (2012).

Indikator-indikator loyalitas diantaranya adalah frekuensi pembelian berulang, peluang pembelian akan datang, minat berganti merek dan komitmen sikap. Frekuensi pembelian berulang ketika nasabah terus berulang menggunakan Mobile Banking yang selama ini digunakan untuk bertransaksi.

Keamanan adalah kemampuan suatu sistem untuk mencegah ilegal atau tidak tepat penggunaan datanya dan untuk mencegah penjahat cyber dan peretas (Shah, 2011). Dalam transaksi perbankan, keamanan merupakan hal utama yang diperhatikan nasabah saat mempercayakan penyimpanan dananya. Jika suatu aplikasi mobile banking dapat menjamin keamanan data maupun transaksi perbankan maka loyalitas nasabah akan semakin meningkat. Rasa aman dapat diartikan saat nasabah merasa aman ketika menggunakan Mobile Banking seperti kebocoran dari user id dan password pengguna Mobile Banking. Kejujuran disini adalah bank menyelenggarakan transaksi Mobile Banking yang jujur, sedangkan terkait dengan penggunaan informasi personal, bank tidak menyalahgunakan informasi personal nasabah. Berdasarkan hal tersebut, maka dirumuskan hipotesis:

\section{H1: Keamanan dapat meningkatkan loyalitas nasabah.}

\section{Hubungan Keandalan dengan loyalitas Nasabah}

Keandalan adalah faktor penting di antara dimensi dominan kualitas layanan tradisional dalam Mobile Banking. Keandalan adalah dasar dari kualitas produk atau layanan Liao \& Cheung, (2002). Definisi keandalan adalah kemampuan untuk melakukan layanan yang dijanjikan secara andal dan akurat. Beberapa peneliti menemukan bahwa peringkat keandalan adalah prediktor yang paling kuat untuk kepuasan pelanggan Zeithaml, Parasuraman, \& Malhotra, (2002).

Indikator-indikator dari faktor keandalan adalah transaksi yang cepat, akurasi informasi tersedia, bahasa informasi mudah dipahami, transaksi lengkap, pemenuhan janji dan layanan benar pertama kali. Transaksi yang cepat adalah transaksi pada Mobile Banking berlangsung cepat. Akurasi informasi tersedia artinya layanan Mobile Banking menyediakan informasi yang benar dan terpercaya. Bahasa informasi pada Mobile Banking mudah dipahami artinya bahasa informasi dalam Mobile Banking tidak membingungkan nasabah dan mudah dimengerti. Transaksi lengkap adalah dalam menggunakan Mobile Banking nasabah pengguna Mobile Banking tuntas menyelesaikan transaksi. Pemenuhan janji artinya layanan Mobile Banking berjalan sesuai yang dijanjikan. Layanan benar pertama kali artinya pertama kali nasabah menggunakan Mobile Banking berjalan dengan baik. Sebuah studi menunjukkan bahwa keseluruhan kualitas layanan yang terdiri dari kepercayaan, keandalan dan daya tanggap secara signifikan mpengaruhi kepuasan dan loyalitas pelanggan (Puriwat \& Tripopsakul, 2017). Berdasarkan hal tersebut, maka dirumuskan hipotesis:

\section{H2: Keandalan dapat meningkatkan loyalitas nasabah}

\section{Hubungan Kepuasan dengan loyalitas nasabah}

Zeithaml, Bitner, \& Dwayne (2009) mendefinisikan kepuasan pelanggan sebagai evaluasi pelanggan terhadap suatu barang atau jasa mengenai apakah barang atau jasa telah memenuhi kebutuhan dan harapan mereka. Fornell, Johnson, Anderson, Cha, \& Bryant (1996), kepuasan pelanggan berarti bahwa pelanggan atau pengguna layanan puas dengan kinerja. Definisi yang diterima oleh sebagian 
besar ahli, kepuasan pelanggan adalah hasil yang diperoleh dari korelasi harapan pelanggan terhadap kinerja dan biaya yang dikeluarkan (Beerli dkk, 2004).

Indikator-indikator yang mempengaruhi kepuasan pelanggan adalah faktor biaya, pengalaman nasabah, akses dan waktu. Faktor biaya dalam hal ini adalah besarnya biaya yang dibebankan Bank untuk nasabah pengguna Mobile Banking apakah mahal atau murah. Pengalaman nasabah dapat dilihat dari kenyamanan dan kemudahan nasabah dalam menggunakan Mobile Banking. Akses terkait dengan kemudahan menggunakan menu-menu dalam Mobile Banking atau User Friendly, sedangkan waktu adalah lamanya proses transaksi menggunakan Mobile Banking, apakah membutuhkan waktu yang lama atau cepat.

Loyalitas dan kepuasan pelanggan sama sekali tidak dipengaruhi oleh citra merek yang bekerja sama, dan loyalitas serta kepuasan pelanggan saling bergantung satu sama lain. Jika pelanggan puas, loyalitasnya meningkat. Oleh karena itu, perusahaan terutama berkonsentrasi pada variabel-variabel ini untuk membuat hubungan jangka panjang yang menguntungkan dengan pelanggan dan meningkatkan citra merek di pasar. Dengan memberikan nilai barang / layanan tinggi dan meningkatkan tingkat kepuasan pelanggan, loyalitas pelanggan dapat dengan mudah dicapai.

Literatur sebelumnya menunjukkan bahwa untuk meningkatkan loyalitas pelanggan, kepuasan pelanggan memainkan peran yang sangat diperlukan dan merupakan pendorong yang paling kritis. Sondoh, dkk (2007) menunjukkan bahwa jika pelanggan puas, loyalitas pelanggan akan meningkat dan karenanya niat pelanggan untuk beralih bank akan berkurang. Shankar, dkk (2003) menunjukkan bahwa pengaruh kepuasan terhadap loyalitas lebih kuat secara online daripada offline. Berdasarkan hal tersebut, maka dirumuskan hipoetsis:

\section{H3: Kepuasan dapat meningkatkan loyalitas nasabah}

Sesuai dengan perumusan masalah serta konsep dan teori acuan yang akan peneliti gunakan, kerangka pemikiran dari penelitian yang akan dilakukan dapat dilihat pada gambar 3:

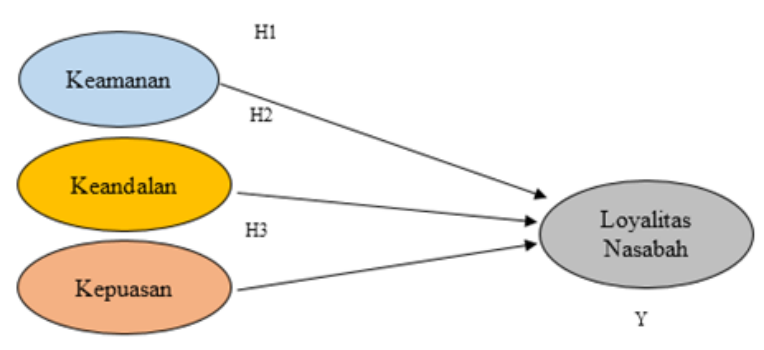

Gambar 3. Kerangka Pemikiran

\section{METODE PENELITIAN}

Penelitian ini menguji tentang pengaruh keamanan, keandalan dan kepuasan terhadap loyalitas nasabah BRI dalam menggunakan Mobile Banking. Berdasarkan tujuan analisisnya, maka rancangan penelitian yang akan digunakan oleh peneliti ini menggunakan Eksplanatif Research karena bertujuan untuk menjelaskan hubungan antara beberapa variabel, yaitu Keamanan, Keandalan dan Kepuasan sebagai variabel independen dan Loyalitas Nasabah sebagai variabel dependen.

\section{Populasi dan Sampel}

Populasi adalah jumlah dari keseluruhan obyek yang karakteristiknya hendak diduga. Mengacu pada pendapat diatas, maka populasi ataupun unit analisis yang akan diteliti adalah nasabah BRI pengguna Mobile Banking yang tinggal di Surabaya. Dalam penelitian ini teknik yang digunakan untuk pengambilan sampel adalah nonprobability sampling. Menurut Sugiyono (2003) nonprobability sampling adalah teknik pengambilan sampel yang tidak memberi peluang atau kesempatan sama bagi setiap unsur atau anggota populasi untuk dipilih menjadi sampel. Jenis 
pengambilan sampel nonprobability sampling yang digunakan pada penelitian ini adalah purposive judgement sampling. Menurut Sugiyono (2003) purposive judgement sampling adalah teknik penentuan sampel dengan pertimbangan tertentu. Adapun kriteria sampel dalam penelitian ini adalah sebagai berikut:

a. Telah berumur minimal 17 Tahun keatas.

b. Nasabah BRI yang telah menggunakan Mobile Banking lebih dari 1 (satu) tahun

c. Nasabah BRI di Kantor Cabang yang berada di Surabaya

Semakin besar sampel diambil, maka akan semakin kecil terjadi kemungkinan salah dalam menarik kesimpulan tentang populasi, dan Ruslan (2010) mengatakan bahwa untuk penelitian yang menggunakan analisis statistik, jumlah sampel yang terkecil adalah 30 subyek/obyek, tetapi pakar peneliti lainnya menganggap bahwa sampel jumlah minimum adalah 100 subyek/obyek yang paling tepat.

Penelitian ini menggunakan tehnik analysis Structural Equation Model (SEM) dengan bantuan Warp PLS. Evaluasi model pada PLS SEM dilakukan melalui dua tahap yaitu evaluasi model pengukuran (outer model) dan evaluasi model structural (inner model). Evaluasi model pengukuran atau outer model dilakukan untuk menilai reliabilitas dan validitas dari indikator-indikator pembentuk konstruk laten. Sedangkan evaluasi model structural atau inner model bertujuan untuk memprediksi hubungan antar variabel laten dengan melihat seberapa besar variance yang dapat dijelaskan dan untuk mengetahui signifikansi dari P-value.

\section{Definisi Operasional dan Pengukuran Variabel \\ Keamanan (X1)}

Keamanan adalah pendapat nasabah mengenai resiko ancaman gangguan mobile banking dan upaya bank meningkatkan keamanan layanan mobile banking, yang meliputi beberapa indikator sebagai berikut: a. Menyimpan data dengan akurat (Nochai \& Nochai, 2013)

b. Keamanan untuk data transaksi dan privasi (Nochai \& Nochai, 2013)

c. Pengecekan histori transaksi (Nochai \& Nochai, 2013)

d. Rasa aman (Nochai \& Nochai, 2013)

e. Kejujuran (Gupta \& Bansal, 2012)

f. Penggunaan Informasi Personal (Gupta \& Bansal, 2012)

\section{Keandalan (X2)}

Keandalan adalah pendapat nasabah mengenai kemampuan layanan mobile banking tetap tersedia dengan baik untuk memenuhi kebutuhan nasabah, yang meliputi indikator sebagai berikut:

a. Transaksi yang cepat (Nochai \& Nochai, 2013)

b. Akurasi informasi tersedia (Ahangar, 2011)

c. Bahasa informasi mudah dipahami (Ahangar, 2011)

d. Transaksi lengkap (Nochai \& Nochai, 2013)

e. Pemenuhan janji (Nochai \& Nochai, 2013)

f. Layanan benar pertama kali (Nochai \& Nochai, 2013)

\section{Kepuasan (X3)}

Kepuasan nasabah adalah pendapat responden mengenai perasaan tingkat kepuasan yang dialaminya dalam penggunaan mobile banking, yang meliputi indikator sebagai berikut:

a. Biaya (Nochai \& Nochai, 2013)

b. Pengalaman nasabah (Nochai \& Nochai, 2013)

c. Akses (Nochai \& Nochai, 2013)

d. Waktu (Nochai \& Nochai, 2013)

\section{Loyalitas Nasabah (Y)}

Loyalitas nasabah adalah komitmen dan keinginan nasabah untuk tetap menggunakan mobile banking bank yang selama ini diguanakan, meliputi indikator sebagai berikut: a. Frekuensi pembelian berulang (Nguyen \& Singh, 2004) 
b. Peluang pembelian akan datang (Nguyen \& Singh, 2004)

c. Minat berganti merek (Nguyen \& Singh, 2004)

d. Komitmen sikap (Nguyen \& Singh, 2004)

Pengukuran variabel yang digunakan dalam penelitian ini adalah skala Likert. Skala Likert adalah skala yang dirancang untuk memeriksa seberapa kuat pernyataan respoden setuju atau tidak setuju Sekaran \& Bougie (2010).

$$
\begin{array}{ll}
\text { Skor 5 } & \text { : Sangat Setuju } \\
\text { Skor } 4 & \text { : Setuju } \\
\text { Skor 3 } & \text { : Ragu-Ragu } \\
\text { Skor 2 } & \text { : Tidak Setuju } \\
\text { Skor 1 } & \text { : Sangat Tidak Setuju }
\end{array}
$$

\section{HASIL DAN PEMBAHASAN}

\section{Evaluasi Model}

Penelitian ini menggunakan tehnik analysis Structural Equation Model (SEM) dengan bantuan Warp PLS. Evaluasi model pada PLS SEM dilakukan melalui dua tahap yaitu evaluasi model pengukuran (outer model) dan evaluasi model structural (inner model). Evaluasi model pengukuran atau outer model dilakukan untuk menilai reliabilitas dan validitas dari indikator-indikator pembentuk konstruk laten. Sedangkan evaluasi model structural atau inner model bertujuan untuk memprediksi hubungan antar variabel laten dengan melihat seberapa besar variance yang dapat dijelaskan dan untuk mengetahui signifikansi dari P-value.

\section{Evaluasi Model Pengukuran (Outer Model)}

Outer model dengan indikator reflektif dievaluasi melalui validitas convergent dan discriminant dari indikator pembentuk konstruk laten (Ghozali \& Latan, 2014). Validitas convergent bertujuan menguji korelasi antar item/indikator untuk mengukur konstruk; sedangkan validitas discriminat bertujuan menguji item/indikator dari dua konstruk yang seharusnya tidak berkorelasi tinggi. Suatu model memiliki validitas convergent apabila nilai loading factor $>0.7$, dan Average Variance Extracted (AVE) $>0.5$ (Hair., dkk. 2019). Namun, model pengukuran dengan nilai loading factor 0.6-0.7 masih dapat diterima untuk exploratory research (Ghozali \& Latan, 2014).

Hasil pengujian outer model menunjukkan bahwa nilai loading factor keamanan berkisar antara 0.840-0.904; keandalan berkisar antara 0.812-0.920; kepuasan berkisar antara 0.801-0.912; loyalitas berkisar antara 0.813-0.945. Hasil analisis menunjukkan bahwa seluruh butir pertanyaan memiliki loading factor di atas 0.70 dan memiliki nilai yang paling besar diantara loading factor butir yang lain. Di samping memenuhi kecukupan loading factor, juga perlu mempertimbangkan nilai AVE untuk memenuhi validitas convergent (Joseph F. Hair dkk, 2019)

Selain harus memenuhi aspek validitas, suatu instrument diharapkan juga mampu menunjukkan akurasi, konsistensi, dan ketepatan suatu alat ukur dalam melakukan pengukuran. Suatu kuisioner dikatakan reliable atau handal jika jawaban seseorang terhadap pernyataan adalah konsisten atau stabil dari waktu ke waktu. Suatu konstruk dikatakan reliable jika koefisien cronbach alpha dan composit reliability lebih besar dari 0.70 (Hair., dkk, 2019). Nilai AVE, composit reliability dan cronbachs alpha ditunjukkan pada tabel 1

Tabel 1. Hasil Validitas Kontruk Variabel

\begin{tabular}{|l|l|l|l|l|}
\hline Variabel & AVE & $\begin{array}{l}\text { Composite } \\
\text { Reliability }\end{array}$ & $\begin{array}{l}\text { Cronbachs } \\
\text { Alpha }\end{array}$ & Status \\
\hline Keamanan & 0.788 & 0.949 & 0.933 & Reliabel \\
\hline Keandalan & 0.732 & 0.932 & 0.908 & Reliabel \\
\hline Kepuasan & 0.729 & 0.931 & 0.906 & Reliabel \\
\hline Loyalitas & $\mathbf{0 . 8 1 4}$ & $\mathbf{0 . 9 4 6}$ & $\mathbf{0 . 9 2 2}$ & Reliabel \\
\hline
\end{tabular}

Sumber: Hasil Analisis Data

\section{Evaluasi Model Struktural (Inner Model)}

Dalam menilai model structural atau inner model dengan PLS, dimulai dengan melihat besarnya presentase variance yang dijelaskan dengan melihat nilai $R$-Squares atau Adjusted R2, effect size, $Q 2$ predictive 
relevance dan $q 2$ predictive relevance. $R$ Squares dapat digunakan untuk memprediksi kekuatan model structural (Ghozali \& Latan, 2014). Perubahan nilai $R$-Squares menjelaskan pengaruh variabel laten eksogen tertentu terhadap variabel laten endogen apakah mempunyai pengaruh yang substantive. Namun selain melihat $R$-Squares juga disarankan untuk melihat nilai Adjusted $R 2$ (Ghozali \& Latan, 2014). Semakin tinggi nilai $R$-Squares semakin baik model prediksi dari model yang diajukan.

Tabel 2 Uji Fit Model

\begin{tabular}{|c|c|c|c|}
\hline Kreteria & Nilai & Kreteria & Status \\
\hline $\begin{array}{l}\text { Average path } \\
\text { coefficient }(A P C)\end{array}$ & $0.275, \mathrm{P}<0.001$ & $\mathrm{P}<0.001$ & Acceptable \\
\hline $\begin{array}{l}\text { Average } R \text {-squared } \\
(A R S)\end{array}$ & $0.320, \mathrm{P}<0.001$ & $\mathrm{P}<0.001$ & Acceptable \\
\hline $\begin{array}{l}\text { Average adjusted } \\
R \text {-squared (AARS) }\end{array}$ & $0.242, \mathrm{P}<0.001$ & $\mathrm{P}<0.001$ & Acceptable \\
\hline $\begin{array}{l}\text { Average block VIF } \\
(A V I F)\end{array}$ & 2.399 & $\begin{array}{l}\begin{array}{l}\text { acceptable if } \\
<=5, \text { ideally } \\
<=3.3\end{array} \\
<=3\end{array}$ & Acceptable \\
\hline $\begin{array}{l}\text { Average full } \\
\text { collinearity VIF } \\
(A F V I F) \\
\end{array}$ & 2.769 & $\begin{array}{l}\begin{array}{l}\text { acceptable if } \\
<=5, \text { ideally } \\
<=3.3\end{array} \\
<\end{array}$ & Acceptable \\
\hline $\begin{array}{l}\text { Tenenhaus GoF } \\
(\text { GoF })\end{array}$ & 0.495 & $\begin{array}{l}\text { small }>=0.1, \\
\text { medium }>= \\
0.25, \text { large }>= \\
0.36\end{array}$ & Large \\
\hline $\begin{array}{l}\text { Sympson's paradox } \\
\text { ratio }(S P R)\end{array}$ & 0.667 & $\begin{array}{c}\text {, acceptable if } \\
>=0.7, \text { ideally } \\
=1\end{array}$ & Acceptable \\
\hline $\begin{array}{l}R \text {-squared } \\
\text { contribution ratio } \\
(R S C R)\end{array}$ & 0.824 & $\begin{array}{l}\text { acceptable if } \\
>=0.9, \text { ideally } \\
\quad=1\end{array}$ & Acceptable \\
\hline $\begin{array}{l}\text { Statistical } \\
\text { suppression ratio } \\
(\text { SSR) }\end{array}$ & 1.000 , & $\begin{array}{l}\text { acceptable if } \\
>=0.7\end{array}$ & Acceptable \\
\hline $\begin{array}{l}\text { Nonlinear } \\
\text { bivariate causality } \\
\text { direction ratio } \\
(N L B C D R)\end{array}$ & 1.000 & $\begin{array}{l}\text { acceptable if } \\
>=0.7\end{array}$ & Acceptable \\
\hline
\end{tabular}

Sumber : Hair et al., (2018); Ghozali \& Latan, (2014)

Selanjutnya untuk mengetahui besarnya proporsi variance variabel eksogen tertentu terhadap variabel endogen, dapat dihitung dengan menggunakan effect size. Nilai tersebut dapat diintepretasikan besar kecilnya pengaruh prediktor variabel laten pada level structural terhadap variabel endogen. Hasil evaluasi model structural (inner model) disajikan pada tabel 3.
Tabel 3. Nilai $R$-Squares, Adjusted $R^{2}$ dan $Q^{2}$ predictive relevance

\begin{tabular}{|l|l|l|l|}
\hline Variabel & $\begin{array}{l}\boldsymbol{R}- \\
\text { Squares }\end{array}$ & $\begin{array}{l}\text { Adjusted } \\
\boldsymbol{R}^{2}\end{array}$ & $\begin{array}{l}\boldsymbol{Q}^{2} \\
\text { predictive } \\
\text { relevance }\end{array}$ \\
\hline Loyalitas Nasabah & $\mathbf{0 . 3 2 0}$ & $\mathbf{0 . 2 4 2}$ & $\mathbf{0 . 5 2 4}$ \\
\hline
\end{tabular}

Sumber: Hasil Analisis Data

Sementara kontribusi effect dari setiap variabel dijelaskan di tabel 4 dimana keamanan memiliki pengaruh kuat terhadap loyalitas dengan nilai effect size 0.211. Sementara kepuasan memiliki pengaruh moderat ke loyalitas dengan nilai effect size 0.196.

Tabel 4. Nilai Effect Size

\begin{tabular}{|l|l|l|l|}
\hline College & X1 & X2 & X3 \\
\hline Y & 0.211 & 0.087 & 0.196 \\
\hline
\end{tabular}

Sumber : Hasil Analisis Data

\section{Pembahasan Hasil Penelitian Hubungan Keamanan dan Loyalitas Nasabah}

Hasil penelitian menunjukkan terdapat hubungan keamanan dengan loyalitas nasabah dengan nilai $\mathrm{p}$ value sebesar 0.02 . Loyalitas menciptakan komitmen pada pelanggan untuk mengeksekusi dengan asosiasi tertentu dan sering membeli barang dan layanannya Hjälte \& Larsson, (2004). Indikator-indikator loyalitas diantaranya adalah frekuensi pembelian berulang, peluang pembelian akan datang, minat berganti merek dan komitmen sikap. Frekuensi pembelian berulang ketika nasabah terus berulang menggunakan Mobile Banking yang selama ini digunakan untuk bertransaksi.

Keamanan adalah kemampuan suatu sistem untuk mencegah ilegal atau tidak tepat penggunaan datanya dan untuk mencegah penjahat cyber dan peretas. Dalam transaksi perbankan, keamanan merupakan hal utama yang perhatikan nasabah saat mempercayakan penyimpanan dananya. Jika suatu aplikasi mobile banking dapat menjamin keamanan data maupun transaksi perbankan maka loyalitas nasabah akan semakin meningkat. 
Dalam menjaga keamanan nasabah bertransaksi mobile banking, BRI telah menerapkan teknologi kriptografi dengan yang akan mengacak dan menyandikan transaksi. Rasa aman dapat diartikan nasabah merasa aman ketika menggunakan Mobile Banking seperti kebocoran dari user id dan password, dan untuk mengantisipasi kondisi tersebut, mobile banking BRI telah dilengkapi dengan teknologi biometric menggunakan sidik jari nasabah. Kejujuran disini adalah bank menyelenggarakan transaksi Mobile Banking yang jujur, sedangkan terkait dengan penggunaan informasi personal, bank tidak menyalahgunakan informasi personal nasabah. Berdasarkan nilai effect size yang dijelaskan di tabel 6, keamanan memiliki hubungan yang paling kuat terhadap loyalitas dibandingkan variabel yang lain. Hal ini membuktikan bahwa keamanan merupakan pertimbangan utama bagi nasabah untuk menempatkan dananya.

\section{Hubungan Keandalan dan Loyalitas Nasabah}

Hasil penelitian menunjukkan bahwa keandalan tidak berpengaruh terhadap loyalitas, yang artinya penurunan maupun peningkatan keandalan system mobile banking BRI tidak mempengaruhi loyalitas nasabah. Hasil ini menolak hipotesis kedua, dengan nilai $\mathrm{p}$ value sebesar 0.18 .

Tidak berpengaruhnya keandalan terhadap loyalitas dapat disebabkan kondisi responden, dimana responden sebagian besar $60 \%$ adalah karyawan swasta serta telah menggunakan mobile banking BRI lebih dari satu tahun. Selain itu, sebagian besar responden telah menggunakan mobile banking BRI lebih dari 1 tahun. Melalui pertanyaan terbuka yang disampaikan kepada responden mengenai alasan mereka menggunakan mobile banking BRI karena payroll gaji perusahaan dimana mereka bekerja adalah melalui BRI sehingga mau tidak mau mereka harus membuka rekening di Bank BRI. Dan selama mereka menggunakan mobile banking BRI mereka merasa puas dengan aplikasi tersebut serta terjaga keamanannya. Hasil penelitian ini menolak hasil penelitian Ali \& Raza (2015) dan Santouridis., dkk (2009).

\section{Hubungan Kepuasan dan Loyalitas Nasabah}

Hasil penelitian menunjukkan terdapat hubungan antara kepuasan dengan loyalitas nasabah dengan nilai $\mathrm{p}$ value sebesar 0.018 , yang maknanya bahwa kepuasan nasabah dapat meningkatkan loyalitas nasabah dalam menggunakan mobile banking BRI. Zeithaml., dkk (2002) mendefinisikan kepuasan pelanggan sebagai evaluasi pelanggan terhadap suatu barang atau jasa mengenai apakah barang atau jasa telah memenuhi kebutuhan dan harapan mereka. Adapun indikator-indikator yang mempengaruhi kepuasan pelanggan adalah faktor biaya, pengalaman nasabah, akses dan waktu.

Faktor biaya dalam hal ini adalah besarnya biaya yang dibebankan Bank untuk nasabah pengguna mobile banking apakah mahal atau murah. Pengalaman nasabah dapat dilihat dari kenyamanan dan kemudahan nasabah dalam menggunakan mobile banking. Akses terkait dengan kemudahan menggunakan menu-menu dalam mobile banking atau user friendly, sedangkan waktu adalah lamanya proses transaksi menggunakan mobile banking, apakah membutuhkan waktu yang lama atau cepat.

Mobile Banking BRI memiliki tampilan yang menarik dan juga menu-menu yang user friendly, sehingga menciptakan pengalaman yang berkesan bagi nasabah. Waktu dan proses transaksi mobile banking BRI cepat dan dengan biaya transaksi yang murah.

Hasil penelitian ini mendukung hasil penelitian sebelumnya yang menunjukkan bahwa untuk meningkatkan loyalitas pelanggan, kepuasan pelanggan memainkan peran yang sangat diperlukan dan merupakan pendorong yang paling kritis (Sondoh., et al, 2007). 


\section{KESIMPULAN DAN SARAN Kesimpulan}

Berdasarkan hasil penelitian, diperoleh hasil menerima hipotesis pertama dan ketiga, serta menolak hipotesis kedua. Penelitian ini membuktikan bahwa keamanan dan kepuasan yang dirasakan nasabah dapat meningkatkan loyalitas nasabah untuk terus menggunakan mobile banking BRI. Sementara keandalan tidak berpengaruh terhadap loyalitas nasabah BRI, hal ini dapat disebabkan mayoritas responden menggunakan mobile banking BRI karena payroll perusahaan tempat mereka bekerja melalui BRI. Sehingga suatu bentuk kepraktisan transaksi bagi nasabah jika menggunakan mobile banking, dan sampai dengan saat ini mereka puas dengan layanan mobile banking BRI.

Berdasarkan hasil penelitian, untuk meningkatkan pengguna mobile banking BRI maka dapat diupayakan untuk menjalin kerjasama pembayaran gaji karyawan perusahaan melalui payroll BRI. Cara ini lebih efektif untuk meningkatkan pengguna mobile banking BRI daripada melalui promosi individu dan untuk terus menjaga loyalitas nasabah perlu terus dilakukan inovasi terhadap fitur-fitur yang ada dalam aplikasi mobile banking BRI sehingga dapat meningkatkan kepuasan nasabah.

\section{DAFTAR PUSTAKA}

Ahangar, R. G. (2011). An Investigation Into The Determinant of Customers Preferences and Satisfication of Internet Banking (Empirical Study of Iranian Banking Industry). Journal of Applied Sciences, 11(3).

Ali, M., \& Raza, S. A. (2015). Measurement of Service Quality Perception and Customer Satisfaction in Islamic Banks of Pakistan: Evidence From Modified Servqual Model. Total Quality Management and Business Excellence, 6(28).

Balbhadra, B., \& Rathod, A. (2016). International Journal of Advance Research in Engineering, Science \&
Technology. System, 2444(5), 1-8. Retrieved from http://www.ijarest.com/papers/finished_p apers/150509234602.pdf

Beerli, A., Martin, J. D., \& Quintana, A. (2004). A Model of Customer Loyalty In The Retail Banking Market. European Journal of Marketing, 38(1), 253-275.

Fornell, C., Johnson, M. D., Anderson, E. W., Cha, J., \& Bryant, B. E. (1996). The American Customer Satisfaction Index: Nature, Purpose, and Findings. American Customer Satisfaction Index, 60(7), 7-18.

Ghozali, I., \& Latan, H. (2014). Partial Least Squares Konsep, Metode dan Aplikasi Menggunakan Program WarpPLS 4.0. Semarang: Badan Penerbit Universitas Diponegoro.

Gupta, K. K., \& Bansal, I. (2012). Development of an Instrument to Measure Internet Banking Service Quality in India. Journal of Arts, Science, and Commerce, 2(2), 4686.

Hair, J. F., Risher, J. J., Sarstedt, M., \& Ringle, C. M. (2018). When to use and how to report the results of PLS-SEM. European Business Review.

Hair, J. F., Risher, J. J., Sarstedt, M., \& Ringle, C. M. (2019). When To use and How to Report the Results of PLS-SEM. European Business Review, 31(1). https://doi.org/10.1108/EBR-11-20180203

Hjälte, S., \& Larsson, S. (2004). Managing Customer Loyalty in The Automobile Industry. International Business And Economics Programme.

Jahanshahi, A. A., Gashti, M. A. H., Miramadi, S. A., Nawaser, K., \& Khaksar, S. M. S. (2011). Study the Effects of Customer Service and Product Quality on Customer Satisfaction and Loyalty. International Journal of Humanities and Social Science, I(7).

Liao, Z., \& Cheung, M. T. (2002). Internet Based E-Banking And Consumer Attitudes. Information and Management 
Journal, 39, 283-295.

Nayebzadeh, S. (2013). The Relationship between Customer Satisfaction and Loyalty with the Bank Performance in Iran. International Journal of Academic Research in Business and Social Sciences, 3(6), 114-124.

Nguyen, T., \& Singh, M. (2004). Impact of Internet Banking on Customer Satisfaction and Loyalty: A Conceptual Model. The Fourth International Conference on Electronic Business, 4(1), 298-303.

Nochai, R., \& Nochai, T. (2013). The Impact of Internet Banking Service on Customer Satisfaction in Thailand: A Case Study in Bangkok. International Journal of Humanities and Management Sciences, 1(1).

Onditi, J., Nderitu, S., Landeo, J. ., Obong, G. ., Sikinyi, E. ., \& Kabira, J. . (2012). Release of three improved varieties for the expanded potato market in Kenya. Agriculture and Biology Journal of North America, 3(5), 192-197. https://doi.org/10.5251/abjna.2012.3.5.19 2.197

Otoritas Jasa Keuangan. (2015). BIJAK BERELECTRONIC BANKING.

Puriwat, W., \& Tripopsakul, S. (2017). the impact of e-service quality on customer satisfaction and loyalty in mobile banking usage: case study of thailand. Polish Journal of Management Studies, 15(2), 183-193.

https://doi.org/10.17512/pjms.2017.15.2. 17

Rosyid, M. I., Ariyanty, M., \& Kusumahadi, K. (2019). Pengaruh E-Servqual dan Kepuasan Pengguna Mobile Banking (MBanking) Terhadap Loyalitas Nasabah Pada Bank BCA Di Bandung. EProceeding of Management, 6(3), 55575566.

Ruslan, R. (2010). Metode Penelitian Public Relation dan Komunikasi. Jakarta: Raja Grafindo Persada.
Santouridis, I., Trivellas, P., \& Reklitis, P. (2009). Internet Service Quality and Customer Satisfaction: Examining Internet Banking in Greece. Total Quality Management and Business Excellence, 20(2), 223-239.

Sekaran, U., \& Bougie, R. (2010). Research Method For Business: A Skill Building Approach (5th ed.). New York: John Wley.

Shah, A. (2011). Factors Influencing Online Banking Customer Satisfaction and Their Importance in Improving Overall Retention Levels: An Indian Banking Perspective. Information and Knowledge Management, 1(1), 45-55.

Shahriari, S. (2014). Effective Factors on Loyalty of E-Banking Customer. International Journal of Advance Research in Computer Science and Management Studies, 2(3), 257-267.

Shankar, V., Smith, A. K., \& Rangaswamy, A. (2003). Customer Satisfaction and Loyalty in Online and Offline Environments. International Journal of Research in Marketing, 20(2), 153-175.

Sondoh, S. L. J., Omar, M. W., Wahid, N. A., Ismail, I., \& Harun, A. (2007). The Effect of Brand Image on Overall Satisfaction and Loyalty Intention In The Context of Color Cosmic. Asian Academy of Management, 12(1), 83-107.

Sugiyono. (2003). Metode Penelitian Bisnis. Bandung: Pusat Bahasa Depdiknas.

Wicaksono, B. S., Kumadji, S., \& Mawardi, M. K. (2015). Pengaruh Self-Service Technology Terhadap Kepercayaan, Kepuasan Nasabah, dan Loyalitas Nasabah (Survei Pada Nasabah PT. Bank Rakyat Indonesia (Persero) Tbk. Kantor Cabang Malang Kawi Kanwil Malang). Jurnal Administrasi Bisnis (JAB), 25(2), 86168.

Zeithaml, V. A., Bitner, M. ., \& Dwayne, D. (2009). Service Marketing (Integratin). New York: Mc Graw Hill.

Zeithaml, V. A., Parasuraman, A., \& Malhotra, 
Journal IMAGE | Volume 9, Number 2, November 2020, page 79-91

A. (2002). Service Quality Delivery through Web Sites: A Critical Review of Extant Knowledge. Journal of the Academy of Marketing Science, 30(4), 362-375. https://doi.org/10.1177/009207002236911 